that preceded the climax and showed what in each instance had caught his fancy.

He loved the French civilization and for this reason, among others, I want to refer to some words by Paul Valéry on how the instinct that keeps driving a man to complete a piece of sustained strenuous mental work is doomed to be antagonized by everything that is not of the spirit. But this resistance, he goes on to say, may bring into life unexpected resources of light and strength. Valéry wrote this of Descartes.

Those privileged to have lived within the radiation of Sherrington's orbit will always remember him as a man in whom the spirit, intellectually as well as emotionally, had explored all its boundaries and returned with unexpected resources of light and strength. Nothing human was alien to him.

Ragnar GrantT

Nobel Institute for Neurophysiology, Stockholm.

'T'HE passing of Sir Charles Sherrington, so many years after the close of his professional labour, must bring to many men a deep sense of sadness.

I can write of it only in terms of our personal relationship. No future Christmas will bring the "remembrances" from him that my wife and I had come to count on. No trip to England can ever again include a pilgrimage to see Sir Charles. But we, who have lived so far from him in body, have never been far from him in mind and now we shall not be cut off from him in spirit.

It was not the example of Horsley or Cushing that led mo into the surgery of the nervous system. It was the inspiration of Sherrington. $\mathrm{He}$ was, so it seemed to $\mathrm{me}$ from the first, a surgical physiologist, and I hoped then to become a physiological surgeon. As years passed his influence did not grow less but stronger. Indeed, it often happens now that, during a routine operation, when the human brain of a conscious patient lies exposed and happy chance makes possible some observation that should throw light on physiological mechanism, I often seem to feel him looking over my shoulder.

In undergraduate days at Oxford, I remember once that he came behind me as I was carrying out my first mammalian experiment. For a little time he watched and then I heard him draw in his breath quickly, in a way he had of doing before he spoke, "You probably know how to do that better than I," he said, "but I should have thought . . .". I flushed and turned to him, thinking, for a moment, that he intended ridicule by his reference to my non-existent knowledge. But I learned better, for he was, of all men I have known, at once the most modest and the most intellectually honest.

In later years it never seemed to occur to him, as it has to one of his defenders, that such conclusions as we could draw from man were at variance with his own thinking. Indeed, he was thrilled by new evidence, and on our visits to him at Eastbourne in his later years, he, who never lost his zest for life, would remark with sparkling eyes, "It must be great fun to have the 'physiological preparation' speak to you".

Following the period of hospital training, I returned to Sherrington for postgraduate study at a time that may well have been the happiest period of his life. It was following the First World War. His son, Carr, had returned safe from overseas and Lady Sherrington was at his side. 'There was time for work and relaxation, for hospitality and reflexion.
No laboratory walls could shut in his spirit. $\mathrm{He}$ was a poet at heart and a philosopher, as well as a physiologist. What Oxford meant to him in those days he expressed in verse :

"The night is fallen and still thou speakst to me,

What though with one voice sole, with accents many,

Tongued turret and tongued stream, tracked pasture, fenny

And cloister, spirit trod, and centuried tree".

Nature did speak to Sir Charles Sherrington in many tongues. Early in life he passed from laboratory observations to an understanding of the integrative action of the nervous system and, in the process, he founded a school of neurophysiology. In later years he continued to hear the voice and interpreted it, though she spoke to him in other accents.

MeGill University,

Wilder Penfield

Montreal.

\section{Mr. W. S. Millard}

ON March 24, W. S. Millard died at Tunbridge Wells in his eighty-fifth year. He was the seventh son of the Rev. J. H. Millard and was born at Huntingdon. In 1887 he went out to Bombay to join the firm of Phipson and Co., and eventually became a partner. The late Herbert Phipson was a remarkable man who, besides founding and carrying on a very successful wine business, was the mainstay of the Bombay Natural History Society, and for eighteen years was secretary and editor of the Society's Journal. In 1893 Millard became joint editor, and when Phipson left India he succeeded him as secretary and held both offices until he finally returned to Britain in 1921. During his period of office the membership of the Society was greatly increased and the Journal enlarged. It was always his aim to encourage naturalists in India to write popular articles to attract more members, which would enable the size of the Journal to be increased and give more room for important scientific papers; in this way he built it up to become the most important scientific periodical in the East.

Millard's name will always be connected with the Mammal Survey of India, Burma and Ceylon, of which he was not only the originator, but also upon him fell the burden of raising money to keep three to four collectors in the field. The Survey began early in 1912, and up to 1915 he had raised Rs. 85,000; when it came to an end in 1923 more than fifty thousand specimens had been collected. Several thousands of skins were presented to the British Museum (Natural History), which now has the finest series of specimens from India, Burma and Ceylon, and made available material for the volumes compiled by Sir John Ellerman and the late Mr. R. I. Pocock.

Millard was a very keen gardener, especially interested in flowering trees and shrubs, and, in conjunction with the late Father Blatter, published in 1927 "Some Beautiful Indian Trees". Through his efforts the gardens of Bombay have been enriched with many fine flowering trees-none more beautiful than Cassia renigera, which he introduced from Burma in 1902.

$\mathrm{He}$ married Sybil, daughter of the late James Mackinlay, of Edinburgh, and is survived by a son and daughter.
N. B. KINNEAR 